\title{
Prevalence, intensity and mean abundance of digenean parasites of the frog Fejervarya sp. (Anura: Dicroglossidae) of the South Western Ghats
}

\section{Keloth Shinad and Puthanpurayil Kandambeth Prasadan*}

Ecological Parasitology and Tropical Biodiversity Laboratory. Department of Zoology. Kannur University. Mananthavady Campus. Wayanad - 670645. Kerala, India.*Email: prasadanpk@kannuruniv.ac.in.

\begin{abstract}
Four species of digenean parasites, Ganeo glottoides, Pleurogenoides cyanophlycti, Tremiorchis ranarum and Encyclometra colubrimurorum infecting the frog Fejervarya sp. (Anura: Dicroglossidae) of the Wayanad Region of the South Western Ghats are reported in this paper. Of the trematode parasites recovered, three, G. glottoides, P. cyanophlycti and T. ranarum, were adults and one, E. colubrimurorum, a metacercaria. Multiple infections were also recorded during the study. Prevalence of infection of G. glottoides, P. cyanophlycti, T. ranarum and E. coloubrimurorum were $1.27 \%, 0.84 \%, 0.84 \%$ and $0.84 \%$, respectively, the intensity of infection $5,1,4.5$ and 1.5 and the mean abundance 0.063, 0.008, 0.038 and 0.012, respectively. Mean abundance is a clear indication of the dispersion of parasites among hosts. The mean abundance, prevalence of infection and the intensity were at the maximum level in G. glottoides infection.
\end{abstract}

Keywords: Digenean parasites; Frog; Fejervarya; Western Ghats; Prevalence.

\section{Introduction}

Frogs harbour a variety of adult and larval trematodes where freshwater gastropods act as first intermediate hosts in their life-cycles. The digenetic
Received

July 8, 2019

Accepted

December 15, 2019

Released

December 31, 2019

Full Text Article

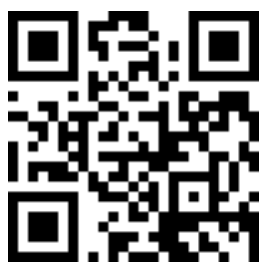

0000-0002-3876-9697

Keloth Shinad

D 0000-0001-7228-8435

Prasadan

Puthanpurayil

Kandambeth 
Agrawal (1966, 1967), Pandey (1968, 1969a, b; 1981), Gupta, (1970, 1977), Mukherjee and Ghosh (1970, 1972), Singh (1977) Janardanan et al. (1987), Janardanan and Prasadan (1991), Brinesh and Janardanan (2014) and Shinad and Prasadan (2017a, b; 2018a, b, c, d). Singh (1977) made the first contribution to the trematode fauna of amphibians in Kerala. From among the major contributors, Janardanan et al. (1987) recorded Pleurogenoides ovatus Rao, 1977 from Rana tigrina (Hoplobatracus tigerinus) and later (1991) they elucidated its life cycle. The life cycle of a new species P. malampuzhaensis was established by Brinesh and Janardanan (2014). Recently four new species of digenetic trematodes from amphibian hosts were reported from the Western Ghats by Shinad and Prasadan (2017a, b; 2018a).

Fejervarya is an Asian frog belonging to the family Dicroglossidae. These are one of the common frogs of the Western Ghats (Frost, 2014) and are often found resting in shallow water and mud in wet and shaded areas. They are normally seen partly buried in mud or sand beside small streams and seepages where it is hard to locate due to their camouflaging colour. It is widely distributed throughout China, Nepal, Bhutan, western and central Myanmar through Bangladesh and India to the northern Pakistan and south to the Western Ghats (Frost, 2014). During our studies on the digenean parasites of frogs of the Western Ghats, Wayanad region, an analysis was made on the species composition of digenean parasites of Fejervarya sp.

This paper reports the digenean parasites infecting Fejervarya sp. of the Western Ghats with their prevalence, intensity of infection and mean abundance.

\section{Materials and methods}

The investigations were made in the South Western Ghats, Wayanad Region (latitudes $11^{\circ} 27^{\prime}$ and $15^{\circ} 58^{\prime} \mathrm{N}$ and longitudes $75^{\circ} 47^{\prime}$ and $70^{\circ} 27^{\prime} \mathrm{E}$ ). Western Ghats is recognized as one of the hottest hotspots of biodiversity due to its very rich fauna and flora and the highest level of endemism.

Two hundred and thirty six specimens of Fejervarya sp. collected during the period from January 2016 to March 2019 from various water bodies using sweep hand net were brought to the laboratory, maintained in cement cisterns and fed occasionally with insects. The specimens were narcotized with chloroform, dissected, their skin were removed, and the muscle tissues were macerated to detect the presence of metacercariae. Internal organs of each frog were dissected out, transferred to separate Petri dishes containing 0.75\% saline, macerated and examined under the Labomed Luxeo4Z stereozoom microscope.

Adults and metacercariae were carefully taken out, transferred to $0.75 \%$ saline in separate watch glasses and studied under phase contrast research microscope (Nikon ECLIPSE Ni-U) without supravital staining or after staining with neutral red. Permanent preparations of adult parasites were made after fixing them in 5\% formalin under slight cover glass pressure and staining with acetocarmine, following the procedure outlined by Cantwell (1981).

Nikon NIS Elements Imaging software was used for the morphometric studies. All measurements are in micrometers $(\mu \mathrm{m})$, as range followed by mean in parentheses. Figures were drawn using the Nikon Y-IDT drawing 
tube attached to the Nikon ECLIPSE Ni-U microscope and the details were added free hand from observations made on live specimens. Photomicrographs were taken with the Nikon Y-TV55 digital camera attached to the phase contrast microscope.Results

Three species of adult digenetic trematodes G. glottoides, P. cyanophlycti, $T$. ranarum and one metacercaria of E. colubrimurorum were found infecting the frog Fejervarya sp. (Tabela 1, Figures 1 to 3 ).

Collection localities: Muthireri, Kalpetta, Peechangode, Kurumbalak kotta, Idikkara, Thalappuzha Engineering College, Valliyoorkavu, Atturkunnu (Pulpally), Thalappuzha, Pakkam, Chandhanathodu, Kannur University Campus Mananthavady, Korom, Sugandhagiri, Neerattadi (Panamaram), Chakadi, Kalluvayal (Batheri), Banasura Chirappullumala, Ondayangadi, Panamaram, Pupally, Birakuppa, Munderi, Batheri, Kambamala, Ellumandam, Karappuzha, Koileri, Ambalavayal, Manivayal, Moolithode, Koolivayal and Pottan kolli Wayanad District.

Period of collection: January 2016 to March 2019.

Table 1. Summary of prevalence, intensity of infection and mean abundance of trematodes under study.

\begin{tabular}{|l|c|c|c|}
\hline Name of the parasite & $\begin{array}{c}\text { Prevalence of } \\
\text { infection }\end{array}$ & $\begin{array}{c}\text { Intensity of } \\
\text { infection }\end{array}$ & Mean abundance \\
\hline Ganeo glottoides & $\begin{array}{c}3 \text { out of } 236 \text { frogs } \\
(1.27 \%)\end{array}$ & $\begin{array}{c}15 \text { from } 3 \text { infected } \\
\text { frogs (5) }\end{array}$ & $\begin{array}{c}15 \text { in } 236 \text { frogs } \\
(0.063)\end{array}$ \\
\hline Pleurogenoides cyanophlycti & $\begin{array}{c}2 \text { out of } 236 \text { frogs } \\
(0.84 \%)\end{array}$ & $\begin{array}{c}2 \text { from } 2 \text { infected } \\
\text { frogs (1) }\end{array}$ & $\begin{array}{c}2 \text { in } 236 \text { frogs } \\
(0.008)\end{array}$ \\
\hline Tremiorchis ranarum & $\begin{array}{c}2 \text { out of } 236 \text { frogs } \\
(0.84 \%)\end{array}$ & $\begin{array}{c}9 \text { from } 2 \text { infected } \\
\text { frogs (4.5) }\end{array}$ & $\begin{array}{c}9 \text { in } 236 \text { frogs } \\
(0.038)\end{array}$ \\
\hline Encyclometra colubrimurorum & $\begin{array}{c}2 \text { out of } 236 \text { frogs } \\
(0.84 \%)\end{array}$ & $\begin{array}{c}3 \text { from } 2 \text { infected } \\
\text { frogs (1.5) }\end{array}$ & $\begin{array}{c}3 \text { in } 236 \text { frogs } \\
(0.012)\end{array}$ \\
\hline
\end{tabular}

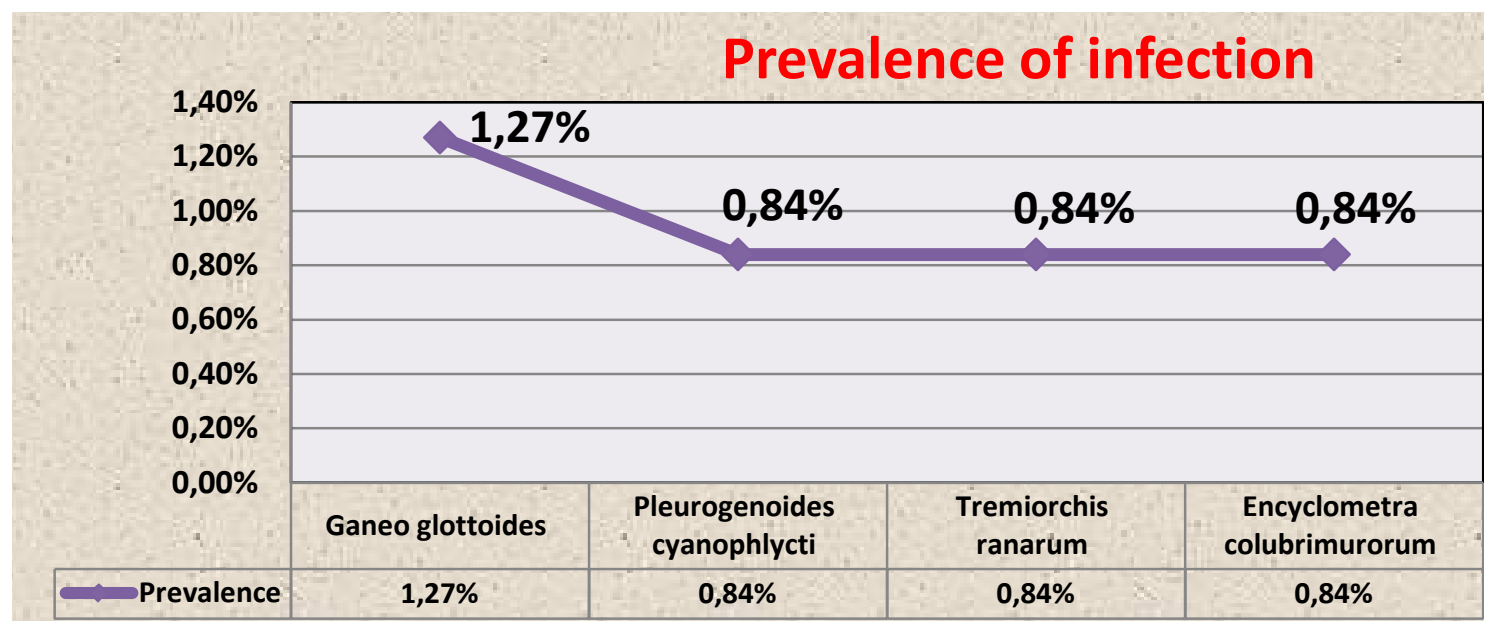

Figure 1. Prevalence of infection of the parasites. 


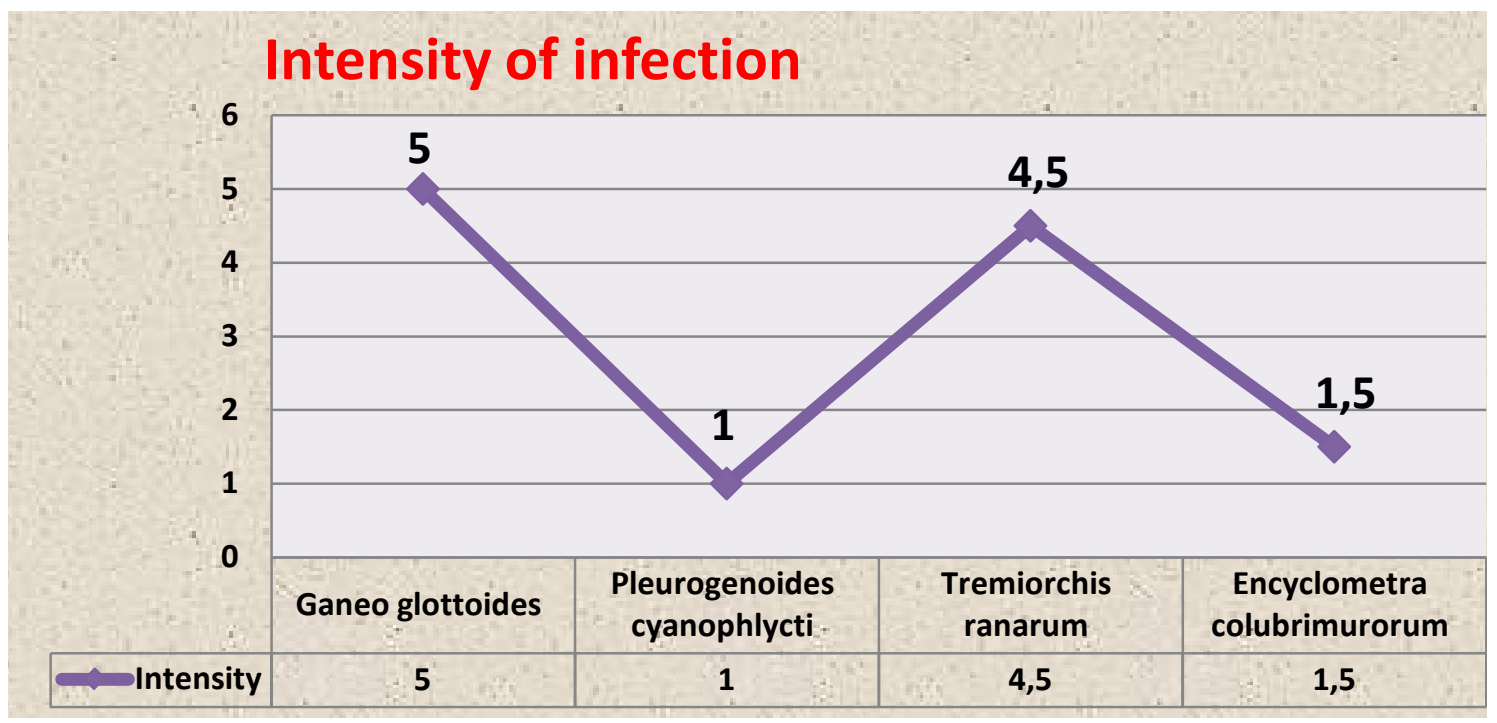

Figure 2. Intensity of infection of the parasites.

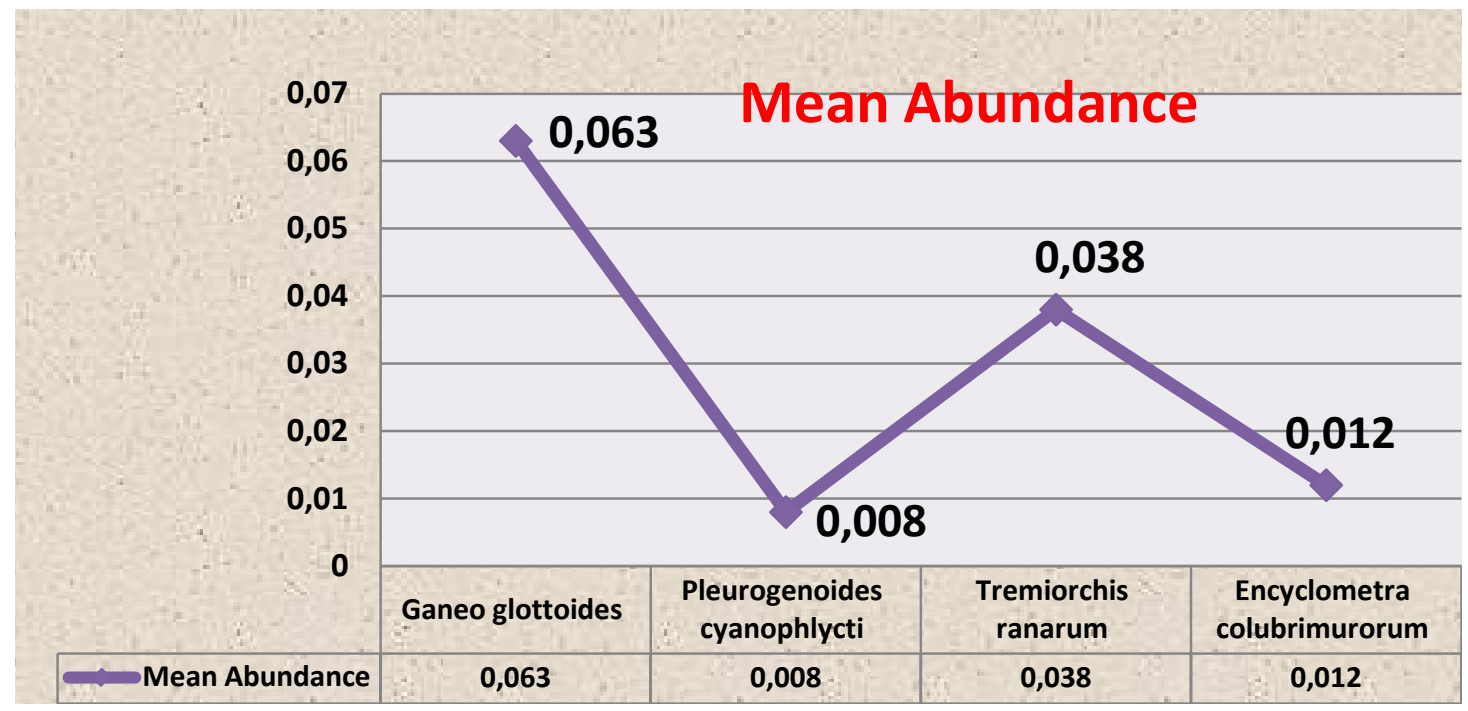

Figure 3. Mean abundance of parasites.

Family: Lecithodendriidae (Luhe, 1901) Odhner, 1901 (Figure 4) Ganeo glottoides Klein, 1905

The genus Ganeo of the family Lecithodendriidae (Luhe, 1901) Odhner, 1901 was proposed by Klein (1905) with $G$. glottoides as its type from $E$. hexadactylus from Tamil Nadu. Since then 17 species have been added to the genus. Fotedar (1959) while reviewing the genus synonymised G. kumaonensis with G. tigrinum. Mukherjee and Ghosh (1970) synonymised $G$. attenuates with $G$. tigrinum. G. kawi and G. gazipurensis were synonymised with $G$. bufonis by Rao (1974) and Gupta and Jahan (1976) respectively. Later Gupta (1977) considered $G$. bufonis as a synonym of $G$. tigrinum. Rao and Kameswari (1976) synonymised G. korkei and G. punjabensis with $G$. tigrinum.

Remarks:The species under study has an elongate oval body with 
bluntly pointed anterior end and broadly round posterior end. Body is covered with small spines which are closely set at the pre-acetabular zone and gradually decrease in number behind ventral sucker. It has a small, circular, sub terminal oral sucker and a slightly larger equatorial ventral sucker. Its mouth is sub terminal and pharynx is thick walled and globular. It has long, narrow oesophagus and intestinal caeca. Testes are obliquely placed, one behind the other, in front of ventral sucker and ovary is round, placed just below the posterior testis. Uterus is coiled, filled with oval operculate eggs. Urinary bladder is V-shaped and vitellaria on the lateral margin up to the posterior onefourth. Cirrus sac is above the ventral sucker. Its gonopore opens on the lateral margin just above the position of caecal bifurcation.

Three out of 236 Fejervarya sp. were infected with $G$. glottoides and the prevalence of infection was $1.27 \%$. Fifteen G. glottoides were recovered from three frogs and the intensity of infection was 5 and 15 G. glottoides were recovered from a total of 236 frogs so the mean abundance was 0.063 (Table 1).

Multiple infection was observed in few frogs with $P$. cyanophlycti, T. ranarum and Clinostomum complanatum.

Collection localities: Peechangode and Ambalavayal, Wayanad District.
A1

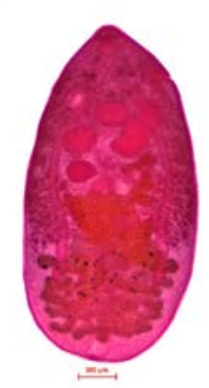

A2

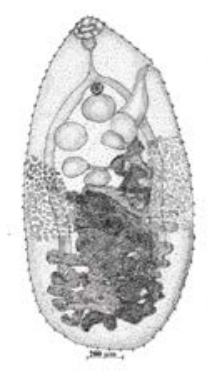

Figure 4. Ganeo glottoides (A1 and A2).

\section{Family: Lecithodendriidae \\ (Luhe, 1901) Odhner, 1901 \\ Pleurogenoides cyanophlycti Shinad and Prasadan, 2017 (Figure 5)}

Based on the length of the intestinal caeca Travassos (1921) established the genus Pleurogenoides of the family Pleurogenidae Looss, 1899 to accommodate those species of the genus, Pleurogenes Looss, 1896, and considered P. tener as its type species. On the basis of the length of intestinal caeca and position of genital pore, Mehra and Negi dropped the genus Pleurogenoides into two sub genera, $\quad P$. (Pleurogenes) and P. (Telogonella). Srivastava, (1934a) also dropped the genus Pleurogenoides and transferred the species under it to Pleurogenes. Macy (1936) retained the genus Pleurogenoides and the same were accepted by Kaw (1943) and Mukherjee and Ghosh (1970). Of the 32 species of Pleurogenoides recorded worldwide from amphibians, 16 species were recorded from India. Life cycles of two species of Pleurogenoides, P. ovatus and P. malampuzhaensis have been elucidated from Kerala (Janardanan and Prasadan, 1991; Brinesh and Janardanan, 2014). Recently three new species of Pleurogenoides, P. cyanophlycti, P. euphlycti and P. wayanadensis were described by Shinad and Prasadan (2017b, 2018a) from E. cyanoplyctis of the Wayanad region of the Western Ghats.

Remarks: The species is characterized by an oval body with a blunt anterior and broadly round posterior ends and the body is covered with minute, backwardly directed spines which are closely set at the anterior region but widely spaced at the posterior end. It has a sub-terminal and almost round oral sucker which is larger than the ventral sucker. Its ventral sucker is spherical and equatorial. Mouth is subterminal with an ovoid and muscular pharynx and short oesophagus. Intestinal caeca bifurcates anterior to ventral sucker into short, blunt, laterally inclined, unequal caecum and ends 
slightly behind testes. It has two slightly spherical or oval, symmetrical testes, at the equatorial or post-equatorial region and one on either side of the ventral sucker in the lateral body margin. Its cirrus sac is claviform extending from the anterior margin of the ventral sucker to genital pore, at the left body margin near the level of oral sucker; it encloses bipartite seminal vesicle, well developed pars-prostatica, long and narrow ejaculatory duct and an un-spinosed cirrus. It has a spherical ovary which is intercaecal and located anterior to right testis. Its uterus is post-acetabular and winding mostly in the hind body region. Its eggs are ovoid, operculate; vitellaria are well developed, extending from the mid-level of oral sucker to the anterior margin of testes, on either side, converging medially, but not meeting together.

Two out of 236 Fejervarya sp. were infected with $P$. cyanophlycti so the prevalence of infection was $0.84 \%$. Two $P$. cyanophlycti were recovered from two frogs and the intensity of infection was one. Its mean abundance was 0.008 as two individual $P$. cyanophlycti were recovered from the 236 Fejervarya sp. examined (Table 1).

A few hosts infected with P. cyanophlycti exhibited multiple infections with G. glottoides.

Collection

Peechangode, Wayanad District.
B1

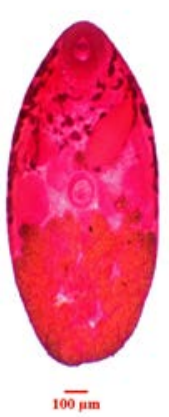

B2

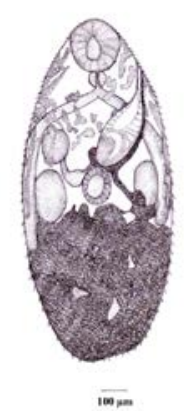

Figure 5. Pleurogenoides cyanophlycti (B1 and B2).
Family: Brachycoelidae

Johnston, 1912

Tremiorchis ranarum Mehra and Negi, 1926 (Figure 6)

Mehra and Negi (1926a) proposed the genus Tremiorchis of the family Brachycoeliidae Looss, 1899 with T. ranarum from $H$. tigerinus as the type species. Ten species of this genus have been reported so far. Pandey and Agarwal (1981) with due justification, considered

T mehrai,

T. vitelloconfluentum, T. tigrinarum, T. mathurensis and T. spiniphlyctis as synonyms of $T$. ranarum. Characters of T.attenuates, T. jamshedpurensis and T.jaini do not validate them as distinct species and they are, therefore, synonyms of $T$. ranarum (Rajendran and Janardanan, 1993). The genus Tremiorchis is therefore monospecific and is restricted to the Indian subcontinent. Rajendran and Janardanan (1993) elucidated the life cycle of T. ranarum.

Remarks: The species is characterized by elongate-oval body with spines on the surface, except at the posterior third. It has a sub terminal and roughly spherical oral sucker and a ventral sucker at about one-third distance from the anterior end of body. Mouth is sub terminal, pharynx is small and thick walled, oesophagus is long narrow and intestinal caeca terminates just behind the anterior margin of anterior testis. It has a pair of round or transversely ovoid testes and a round ovary. Numerous small eggs are present.

Two out of 236 Fejervarya sp. were infected with $T$. ranarum so the prevalence of infection was $0.84 \%$. Nine T. ranarum were recovered from two frogs and the intensity of infection was 4.5 and nine $T$. ranarum were recovered from a total of 236 frogs so the mean abundance was 0.038 (Table 1).

Few frogs infected with T. ranarum exhibited multiple infections with G. glottoides and C. complanatum.

Collection localities: Pulpally and Ambalavayal, Wayanad District. 
C1

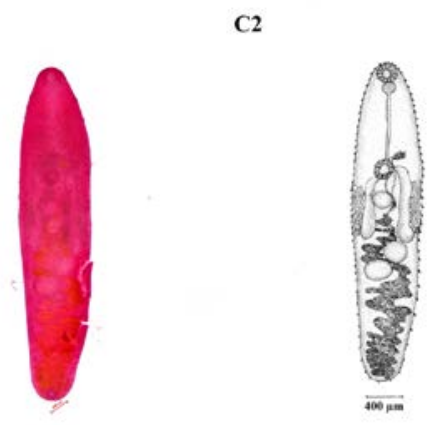

Figure 6. Tremiorchis ranarum (C1 and C2).

\section{Family: Plagiorchiidae (Luhe, 1901) Ward, 1917 \\ Metacercaria of Encyclometra colubrimurorum (Rudolphi, 1819) Dollfus, 1929 (Figure 7)}

The genus Encyclometra was proposed by Baylis and Cannon in 1924 of the family Plagiorchiidae (Luhe, 1901) Ward, 1917. As far as is known, only four species of the genus Encyclometra have been reported. Adults of all the four species have been reported from India. Mehra (1931) from Natrix piscator and N. mucosus at Allahabad (U.P.); Bhalerao (1926, 1936) reported it from Ptyas (=Zamensis) mucosus at Culcutta; Gupta (1954) from N.piscator Ludhiana (Punjab); Srivastava and Ghosh (1968) from the snakes, namely $P$. mucosus, N.piscator, N. stolata and Atretium schistosum from Culcutta (West Bengal) and Patna (Bihar); Dwivedi and Chauhan (1970). The adults of E. colubrimurorum were recorded from Turkey (Düsen and Oz, 2004; Capuse, 1971; Biserkov, 1996; Shimalov and Shimalov, 2000). Fischthal and Kuntz (1965, 1967) reported E. colubrimurorum, infecting E. plumbea from North Borneo and Korea. The lifecycle of the genus has not so far been elucidated. Metacercariae of E. colubrimurorum and E. asymmetrica have been reported by Yamaguti (1936) and Chiang (1951) respectively. Nature of the intestinal caeca is a constant and reliable character to differentiate the various species of this genus. The first report of E.colubrimurorum metacercaria from India was made from the tadpole of $C$.curtipes and the adult frog (Fejervaria $s p$ ) and the morphological characters of the metacercaria is done by Shinad and Prasadan (2018b).

Remarks: This species has two structural variations, an elongate and a small ovate. Body is fusiform and aspinose. It has a small, oval, subterminal oral sucker and a slightly larger equatorial and oval to round ventral sucker. Mouth is sub terminal; pharynx is muscular thick walled and oval to round. It has short oesophagus. Pharynx and oesophagus are surrounded by gland cells. It has a long, asymmetrical and unequal intestinal caeca extended almost up to the posterior end of body. Testes are fairly developed, round to ovoid and tandemly placed in the posterior half of body and ovary is small ovoid located just behind the acetabulum. Excretory bladder is large, saccular filled with concretions and extending from the posterior end to just below the acetabulum. Excretory pore is terminal. Cirrus sac is poorly developed, immediately above the anterior border of acetabulum.

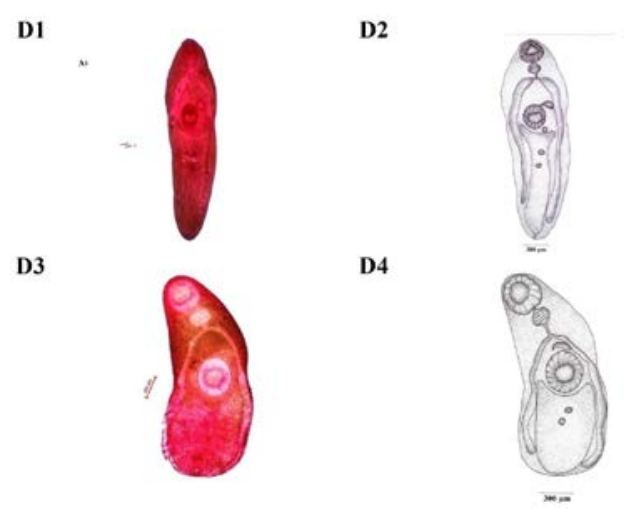

Figure 7. Metacercaria of Encyclometra colubrimurorum (D1, D2, D3 and D4). 


\section{Acknowledgements}

The authors are grateful to the Kerala State Council for Science, Technology and Environment (KSCSTE), Government of Kerala for providing financial assistance in the form of a major research project (SRS/220/2015/ KSCSTE) to carry out this study. The permission accorded by the Department of Forest and Wildlife, Government of Kerala (Order No WL10-63909/2016) for collecting frogs from the Wayanad forest region is also gratefully acknowledged. The authors are indebted to Prof. K. P. Janardanan for critically going through the manuscript.

\section{Conflict of interest}

Authors declare that there are no conflicts of interest.

\section{Ethical approval}

All applicable international, national, and/or institutional guidelines for the care and use of animals were followed. All procedures performed in the study involving animals were in accordance with the ethical standards of the institution or practice at which the study was conducted.

\section{References}

Bhalerao, G. D. On the trematodes of the digestive tract of a common Indian frog, Rana tigrina, with a description of Centrovitus pentadelphi n.g.; n.sp. Parasitology, v. 18, p. 154-159, 1926. https://doi.org/10.1017/ S0031182000005102

Bhalerao, G. D. Studies on the helminths of India. Trematoda I. Journal of Helminthology, v. 14, no. 3, p.163-180, 1936a. https://doi.org/10.1017/S0022149X 00003679

Bhalerao, G. D. Studies on the helminths of India. Trematoda II. Journal of Helminthology, v. 14 , no. 4, p.181-206, 1936b. https://doi.org/10.1017/S0022149X 00004089

Bhalerao, G. D. Studies on the helminths of India. Trematoda III. Journal of Helminthology, v. 14, no. 4, p. 207-228, 1936c. https://doi.org/10.1017/S0022149X 00004090

Bhalerao, G. D. Studies on the helminths of India. Trematoda IV. Journal of Helminthology, v. 15, no. 2, p. 97-124, 1937. https://doi.org/10.1017/S0022149X000307 53

Biserkov. V.Y. New records of Platyhelminthes parasites from snakes in Bulgaria. Comptes rendus de l'Academie Bulgare des Science, v. 49, p. 73-75, 1996.

Brinesh, R.; Janardanan, K. P. The life history of Pleurogenoides malampuzhensis sp. nov. (Digenea: Pleurogenidae) from amphibious and aquatic hosts in Kerala, India. Journal of Helminthology, v. 88, p. 230-236, 2014. https://doi.org/10.1017/S0022149X130000 84

Cantwell, G. E. Methods for invertebrates. In: Clark, G. (Eds.). Staining procedures. Baltimore: Williams and Wilkins, 1981. p. 255-280.

Capuse, I. Contributions a l'etude des trematodes parasites chez les reptiles du Roumanie. Travaux du Muséum d'Histoire Naturelle “Grigore Antipa”, v. 11, p. 33-40, 1971.

Chauhan, B. S. Studies on the trematode fauna of India. Part. IV. Subclass Digenea (Prosostomata) (A revision of Hemiuroidea from Indian Region). Records of Indian Museum, v. 51, p. 289-393, 1954.

Chiang, C. P. A comparative study of two species of Encyclometra metacercariae and their development in experimental hosts (Trematoda: Plagiorchiidae). Ling. Science Journal, v. 23, p. 201-215, 1951.

Düsen, S.; Oz, M. Helminth parasites of the tree frog, Hyla arborea (Anura: Hylidae) from Southwest Turkey. Comparative Parasitology, v. 71, no. 2, p. 258-261, 2004. https://doi.org/10.1654/4123

Dwivedi, M. P.; Chauhan, B. S. On some digenetic trematodes. Part III. Journal of the Zoological Society of India, v. 22, p. 165172, 1970. 
Fischthal, J.H.; Kuntz, R. E. Digenetic trematodes of amphibians and reptiles from North Borneo (Malaysia). Proceeding of the Helminthological Society of Washington, v. 32, p. 124-136, 1965.

Fischthal, J. H.; Kuntz, R. E. Digenetic trematodes of amphibians and reptiles from Fiji, New Hebrides and British Solomon Islands. Proceeding of the Helminthological Society of Washington, v. 34, p. 244-251, 1967.

Fotedar, D. N. On a new species of the genus Ganeo Klein, 1905 and some notes on the genus. Journal of Helminthology, v. 33, no. $2 / 3$, p. 151-160, 1959. https://doi.org/ $10.1017 / \mathrm{S} 0022149 \times 00033393$

Frost, D. R. Amphibian species of the world. Version 6.0. Electronic database, 2014. Available from: <http://research.amnh.org/ vz/herpetology/amphibia/>. Accessed on: Apr. 23, 2019.

Gupta, S. P.; Agarwal, V. Two trematode parasites of Rana cyanophlictis from Udaipur (Rajastan). Proceedings of the National Academy of Sciences, India Section B: Biological Sciences, v. 36, p. 530-536, 1966.

Gupta, S. P.; Agrawal, V. On a new trematode, Halipegus udaipurensis n. sp. from Rana cyanophlyctis from Udaipur. Indian Journal of Helminthology, v. 19, p. 77-80, 1967.

Gupta, V.; Jahan, A. On two new trematode parasites of amphibian from Lucknow. Indian Journal of Helminthology, v. 28, p. $141-147,1976$.

Gupta, P. D. Fauna of Rajastan, India, Part 8. Trematoda. Records of the Zoological Survey of India, v. 62, p. 171-190, 1970.

Gupta, P. D. Studies on the genus Ganeoi Klein, 1905 (Trematoda. Lecithodendridae). Records of the Zoological Survey of India, v. 72, p. 281-290, 1977.

Janardanan, K. P.; Prasadan, P. K. Studies on the life-cycle of Pleurogenoides ovatus Rao, 1977 (Trematoda: Pleurogenetinae). Journal of Helminthology, v. 65, no. 1, p. 43-50, 1991. https://doi.org/10.1017/S0022149X 00010427

Janardanan, K. P.; Shanavas, K. R.; Usha, N. V. On the progenetic metacercaia of Pleurogenordes ovatus Rao, 1977 (Trematoda: Pleurogenetinae) from the freshwater crab, Paratelphusa hydrodromous
(Herbst), with observation on its in vitro excystment. Zoologischer Anzeiger, v. 219, p. 313-320, 1987.

Kaw, B. L. Studies on the helminth parasites of Kashmir. Part II. On two new trematodes of the Sub-Family Pleurogenetinae Looss (1899) with a review of the genus Pleurogenes Looss (1896). Proceedings of the National Academy of Sciences, India Section B: Biological Sciences, v. 18, p. 97108, 1943.

Klein, W. Neue Distomen aus Rana hexadactyla. Zoologische Jahrbücher. Abteilung für Systematik, Geographie und Biologie der Tiere, v. 22, p. 1-22, 1905.

Macy, R. W. A new genus and species of trematodes from the little brown bat, and a key to the genera of Pleurogenetinae. Proceedings of the United States National Museum, v. 83, p. 321-324, 1936.

Mehra, H. R. Two distomatic trematodes from Indian Reptiles. Allah Univiversity Study, v. 7, p. 31-52, 1931.

Mehra, H. R.; Negi, P. S. On a new trematode Tremiorchis ranarum nov. gen. spec. from the common Indian frog Rana tigrina. Parasitology, v. 18, p. 168-181, 1926a.

Mehra, H. R.; Negi, P. S. The trematode parasites of Rana tigrina of the Family Pleurogenetinae Luhe. Proceedings of the Indian Science Congress, v. 13, p. 185-186, 1926b.

Mehra, H. R.; Negi, P. S. Trematode parasites of the Pleurogenetinae from Rana tigrina with a revision and synopsis of the sub family. Allah Univiversity Study, v. 4, p. 63$118,1928$.

Mukherjee, R. P.; Ghosh, R. K. Studies on some amphibian trematodes from Uttar Pradesh and West Bengal. (Part I). Indian Journal Helminthology, v. 22, p. 61-78, 1970.

Mukherjee, R. P.; Ghosh, R. K. Studies on some amphibian trematodes from West Bengal and Maharashtra (Part II). Records of the Zoological Survey of India, v. 66, p. 273276, 1972.

Pande, B. P. On some digenetic trematodes from Rana cyanophlyctis of Kumaon Hills. Proceedings of the Indian Academy of Sciences - Section B, v. 6, p. 109-120, 1937. https://doi.org/10.1007/BF03051116 
Pandey, K. C. A redisription of Halipegus mehransis Srivastava 1933 from the common Indian frog, Rana cyanophlictis Schneider. Indian Journal Helminthology, v. 21, p. 109114, 1969b.

Pandey, K. C. On a new trematode Diplodiscus chauhani n. sp. from the common Indian frog, Rana cyanophlictis Schneider. Indian Journal of Helminthology, v. 29, p. 203-206, 1969a.

Pandey, K. C.; Agarwal, N. Further remarks on the genus Tremiorchis Mehra and Negi, 1925. Proceedings of the Indian Academy of Sciences Animal Sciences, v. 90, p. 567-570, 1981.

Pandey, K. C.; Chakrabarti, K. K. On a new trematode Diplodiscus lali n. sp. from the common Indian frog Rana tigrina Daud. Ceylon Journal of Science (Biological Sciences), v. 8, p. 38-41, 1968.

Rajendran, K. V.; Janardanan, K. P. Studies on the life-cycle of Tremiorchis ranarum. Journal of Helminthology, v. 67, p. 95-101, 1993. https://doi.org/10.1017/S0022149X 00012955

Rao, L. N. A note on the synonymy of Ganeo kawi Dwivedi and Chauhan, 1970 with G. bufonis Fotedar, 1959. Current Science, v. 43, p. 285-286, 1974.

Rao, L. N.; Kameswari, M. On the synonymy of Ganeo korkei Bhalerao, 1936 and G. punjabensis Gupta, 1954 with G. tigrinum Mehra and Negi, 1928. Current Science, v. 45, p. 623-624, 1976.

Shimalov, V. V.; Shimalov, V. T. Helminth fauna of snakes (Reptilia, Serpentes) in Belorussian Polesye. Parasitology Research, v. 86 , p. $340-341,2000$. https://doi.org/ $10.1007 / \mathrm{s} 004360050055$

Shinad, K.; Prasadan, P. K. Description of Diplodiscus cyanophlycti n. sp. (Digenea: Paramphistomidae) and prevalence and intensity of two other digeneans infecting the water skipper, Euphlyctis cyanophlyctis from the Western Ghats, India. International Journal of Fisheries and Aquatic Studies, v. 5, no. 6, Part D, p. 259-263, 2017.

Shinad, K.; Prasadan, P. K. Two new species of Pleurogenoides (Luhe, 1901) Travassos, 1921 (Digenea: Pleurogenidae) infecting two species of frogs of the Western Ghats, India. Journal of Parasitic Diseases, v. 42, p. 130-
136, 2018a. https://doi.org/10.1007/ s12639-018-0978-y

Shinad, K.; Prasadan, P. K. First record of Encyclometra colubrimurorum (Rudolphi, 1819) Dollfus, 1929 (Digenea: Plagiorchiidae) metacercariae from a tadpole and an adult frog of the Western Ghats, India. International Journal of Fisheries and Aquatic Studies, v. 6, p. 135-139, 2018b.

Shinad, K.; Prasadan, P. K. Prevalence, intensity and mean abundance of Digenean parasites of the water skipper, Euphlyctis cyanophlyctis (Anura, Dicroglossidae) of the South Western Ghats. International Journal of Fisheries and Aquatic Studies, v. 6, no. 6, p. 278-284, 2018c.

Shinad, K.; Prasadan, P. K. Digenean parasites of the water skipper Euphlyctis cyanophlyctis (Schneider, 1799) (Anura: Dicroglossidae) of the South Western Ghats, India. Brazilian Journal of Biological Sciences, v. 5, no. 11, p. 747-756, 2018d. https://doi.org/ 10.21472 /bjbs.051112

Singh, M. S. Studies on the amphibian trematodes from Tamil Nadu and Kerala. Records of the Zoological Survey of India, v. 72, p. 291-294, 1977.

Srivastava, H. D. On new trematodes of frogs and fishes of the United Provinces, India. Part. I. Distomes of the Family Hemiuridae from North Indian fishes and frogs with a systematic discussions of the Family Halipegidae and the genera Vitellotrema Guberlet and Genarchopsis Ozaki. Bulletin of the Academy of Sciences of the United Provinces of Agra and Oudh, v. 3, p. 1-60, 1933a.

Srivastava, H. D. On new trematodes of frogs and fishes of the United Provinces, India. Part II. Three new trematodes of the Subfamily Pleurogenetinae (Family Lecithodendriidae) from Rana cyanophlyctis of Oudh. Bulletin of the Academy of Sciences of the United Provinces of Agra and Oudh, v. 3, p. 41-60, 1933b.

Srivastava, H. D. On new trematodes of frogs and fishes of the United Provinces, India. Part III. On a new genus Mehraorchis and two new species of Pleurogenes (Pleurogenetinae) with a systematic discussion and revision of the Family Lecithodendriidae. Bulletin of the Academy of Sciences of the United 
Provinces of Agra and Oudh, v. 3, p. 239256, 1934a.

Srivastava, H. D. On new trematodes of frogs and fishes of the United Provinces, India. Part. IV. The occurrence and seasonal incidence of infection of certain trematodes of the above hosts. Bulletin of the Academy of Sciences of the United Provinces of Agra and Oudh, v. 4, p. 113-119, 1934b.

$\begin{array}{llll}\text { Srivastava, } & \text { C. B.; Ghosh, } \quad \text { R. K. On }\end{array}$ Encyclometra bungara n. sp. (Trematoda: Plagiorchidae) from the Indian Banded crait, Bungarus faciatus (Schneider), with new host records of E. japonica. Indian Journal of Helminthology, v. 20, p. 132-135, 1968.
Travassos, L. Contribuição para o conhecimento da fauna helmintológica brasileira. XII. Sobre espécies brasileiras da Sub-Família Brachycoelinae. Arquivo da Escola Superior de Agricultura e Medicina Veterinária, v. 5, no. 1/2, p. 73-79, 1921.

Yamaguti, S. Studies on the helminth fauna of Japan. Part 14. Amphibian trematodes. Japanese Journal of Zoology, v. 6, no. 4, p. 551-576, 1936. 